\title{
Natural capital as a factor in regional competitiveness
}

\begin{abstract}
Environmental resources and values (natural capital) should be seen as a key factor in regional competitiveness. However, little attention has been paid so far to the role of natural capital in the process of achieving competitive advantage from the territorial perspective. Therefore, the main purpose of this paper is to present the results of a study on the environmental competitiveness of Polish regions. The author's contribution to the theory is the use of taxonomic metrics for research purposes. Based on certain predefined criteria the environmental potential of each voivodship was assessed in 2004 and 2012. For research purposes, 26 indicators of state, pressure, and environmental protection were proposed. Owing to the fact that the subset of diagnostic variables (indicators) contained elements that could not be directly aggregated, their unification was achieved using standardization formulas. The methodology proposed by the author might be used to assess environmental competitiveness in different regions or countries. The results of the performed analyses indicated that the Subcarpathian province scored highest in terms of environmental competitiveness, while Swiętokrzyskie province scored lowest.
\end{abstract}

Keywords

Natural capital $\bullet$ environment $\bullet$ region $\bullet$ competitiveness $\bullet$ regional development - Poland

(C) University of Warsaw - Faculty of Geography and Regional Studies

Introduction

In the implementation of environmental policy, Poland adopted a strategy of sustainable development (ecodevelopment), according to which the obligation to protect the natural environment is a part of proper management and cannot be treated as conflicting with the interests of the economy. Any activity that contravenes this obligation is considered illegal. Regardless of the definition, the critical views (Sztumski 2009; Jędrusik 2014) or the importance of individual areas (planes) of interest in terms of sustainable development (Pawłowski 2013), there is a need to emphasize the important role that the environment's resources and values play in the process of socioeconomic development. However, little attention has been paid so far to the role of natural capital in the process of achieving a competitive advantage, especially at the regional level.

Local governments must address the issue concerning the competitiveness and attractiveness of external firms. Growth strategies for regions must rely on the so-called 'territorial capital', which means the proper exploitation of local assets and potentials (Camagni 2008, Camagni \& Capello 2013). The concept of territorial capital is therefore related to the concept of territorial competitiveness (at the regional and/or international level), which determines the size and importance of a territory's potential in achieving high and sustainable rates of growth in living standards. On this basis, regional competitiveness is characterized in two ways: as a combined measure of the enterprise competitiveness in a region and as competitiveness stemming from macroeconomic competitiveness.

According to D.-L. Constantin (2006), regional competitiveness seems to be a concept situated between these two ways, and

\author{
Armand Kasztelan \\ Department of Management and Marketing \\ University of Life Sciences in Lublin \\ Poland \\ e-mail: armand.kasztelan@up.lublin.pl \\ Received: 27 November 2014 \\ Accepted: 15 June 2015
}

to define and understand it, it is crucial to identify the factors describing it. Wokoun et al. (2012) divide the factors for regional competitiveness into universal and specific. Universal factors are those that are of general importance and their significance has been proven during studies on regional development. Specific factors are those that can be identified only in some regions and reflect the individual conditions of these regions; however, in terms of competitiveness, they may be quite significant (e.g. raw materials or general natural capital). R. Rucinska and R. Rucinsky (2007) state that regional competitiveness is a function of the indicators determining the ability of a region to compete with other regions (drivers) and the results that regional competitiveness has brought (outcomes). In this context, they treat natural resources as one of the main drivers that creates the exogenous factors of a region. In their opinion, natural capital is the source of static, competitive advantages for the region, because it derives from conditions given to the region by its natural environment.

The high quality of the environment, supported by the low levels of pollution can be considered as a kind of trademark that can influence regional development. It contributes to overall wellbeing and it assists the further improvement of the environment. Taking active measures to protect the environment promotes the so-called 'green' specialization of regions, thereby increasing their competitiveness at the national or even international level.

The thesis that a clean environment (environmental quality) is a significant element in the formation of competitive advantage on a meso-economic level may be put based on the considerations. Regions with a relatively clean environment should develop those 
sectors of economic activity that to a higher or lower extent use (in a sustainable manner) resources and values of the environment.

This article describes the importance of natural capital in achieving a competitive advantage at the meso-economic level (NUTS 2 regions). The essence of the environmental competitiveness of regions, and its developmental factors, are discussed. The main purpose of the paper is to assess the environmental potential of Polish voivodships using taxonomic methods.

The role of natural capital in regional competition processes

The concept of natural capital is based on the economic definition of capital as a specific resource which will generate a stream of goods and services of value. Here it is important to define the nature of resources as "input", i.e. irrespective of whether they arise in the manufacturing processes or are a product of nature (the natural environment). This distinction remains the basis of the allocation of capital to anthropogenic and natural categories.

According to R. Costanza and H. E. Daly (1992), two types of natural capital can be distinguished: renewable (active) natural capital and non-renewable (inactive) natural capital. Renewable capital is active and is self-sustaining with the use of solar energy. Examples are ecosystems that, on the one hand, generate particular products (e.g. wood) and on the other hand, specific services (for instance, preventing the processes of erosion or recreational services). Non-renewable natural capital is more passive. Examples are fossil fuels and minerals which do not provide any services unless they are mined from the earth's surface.

Natural resources have previously been treated as public goods, but due to the competition for their use (for example, water), this way of thinking must be regarded as invalid. While the consumption of resources was low and the possibility of the regeneration of natural processes was sufficient to maintain the ecological balance, this misconception was not meaningful. Unfortunately, the progress of civilization has led to a situation in which environmental goods, together with the services they provide, compete in terms of use. The problem is that the limited quantity (or even deficiency) of natural resources is not reflected in the prices of these goods (either they are not paid for at all, or their cost is minimal), and thus the price mechanism has led to excessive demand, or misallocation. As resources and environmental values produce positive externalities, they should be treated as substantive goods (collective), the comprehensive protection of which requires state intervention (Bartmann 1996). The above-mentioned elements of natural capital have important functions, without which man could not survive. The general classifications, which can be found in the literature (Ekins et al. 2003, Degórski 2010, Madej 2002), indicate:

1. the functions determining life (primary, ontological, ecological): related to the creation of biological infrastructure, which consists of components of the environment that affect life on Earth; the ability to maintain a healthy and fully functional ecosystem, ozone layer, climate, etc.

2. the resource-formative function (ecological): related to environmental and technical infrastructure, which is dominated by the components of the natural environment that determine the processes of production and consumption crucial to the continuity of business processes (current and long-term continuity, which is important for future generations).

3. the neutralizing function (absorbing, sozological, regulatory): the ability to neutralize, to some extent, the waste and pollution generated by humans without affecting other functions of ecosystems.
4. the health-oriented and social function (cultural and civilizational): cultural, recreational, aesthetic, scientific, spiritual; the natural environment affects the beyondeconomic sphere of human activity and its system of values.

The ability of natural capital to provide these functions is protected by ecological processes (processes of the ecosystem), and sustained by maintaining biodiversity. Many of these functions cannot be replaced by human-made capital. The increasing impact of humans on the biosphere results in the progressive destruction of biodiversity and weakening of ecosystem processes, and thus threatens the various functions of ecosystems (Michałowski 2012). These processes are becoming one of the major problems in terms of socio-economic development. Loss of ecosystem services may indeed have a significant impact on the development of future opportunities. Moreover, the unequal distribution of resources is a source of additional benefits or disadvantages for economic entities. Existing differences in accessibility, quality and costs of resources, acceptable standards of pollution and treatment costs are an important part of building a competitive advantage. (Ehrlich \& Wilson 1991, Malovics 2007, Martin 2005).

Borozan (2008) states that regional competitiveness is not oriented towards the exploitation of resources, but assumes the identification of growth potentials, while taking into account special constraints and strengthening the unique combination of resources in order to create favourable conditions in which to live and work. In other words, it refers to the innovative and entrepreneurial conversion of these resources into intellectual capital, added value, economic growth and development.

According to the proposed definition, achieving a competitive advantage over other regions based on existing environmental potential, the ability of natural capital to be used in socialeconomic growth and development processes and a low level of anthropopression, may be defined as the environmental competitiveness of the region (Kasztelan 2010).

Different research and analytical methods may be applied to assess the environmental competitiveness of particular regions. This will allow identification of those regions that are characterized by relatively high environmental potential, and thus may direct their development strategies towards processes making use of environmental resources and values. Conducting this kind of analysis should also create the basis for processes of regional specialization taking into account environmental factors.

\section{Material and methods}

Previous studies on environmental competitiveness of regions in Poland (Kasztelan 2011, 2013a, 2013b,) were based on the use of the so-called ranking method (scoring). For the purposes of analysis, indices of the condition and protection of the environment as well as pressures placed on the environment were selected. Points 1 to 16 were attributed to the voivodships within particular indices (division of 16 NUTS 2 regions is applicable in Poland), depending on the position occupied on a national level with respect to a given factor. Then, the points attributed within particular indices were totalled, producing a total result for each voivodship. This relatively simple method allowed for the preliminary assessment of the environmental competitiveness of regions in Poland.

At the present stage of the study, a taxonomic linear ordering method (taxonomic classification) is used to assess the environmental competitiveness of the regions (Hellwig 1968). Taxonomic procedures are used in the study of complex, phenomena that cannot be measured directly(e.g. environmental competitiveness of regions). They are described by at least several diagnostic variables (e.g. indicators of the state, pressure 
Table 1. Diagnostic variables - indicators of state, pressure, and environmental protection

\begin{tabular}{|c|c|c|}
\hline No. & Indicator & $\begin{array}{l}\text { Character: } \\
\text { Stimulant/ De-stimulant }\end{array}$ \\
\hline 1 & The proportion of organic land within the overall area of the voivodship (as \%) & $\mathrm{S}$ \\
\hline 2 & The proportion of forested land within the overall area of the voivodship (as \%) & $\mathrm{S}$ \\
\hline 3 & $\begin{array}{l}\text { The proportion of land under surface waters within the overall area of the voivodship } \\
\text { (as \%) }\end{array}$ & $\mathrm{S}$ \\
\hline 4 & $\begin{array}{l}\text { The proportion of devastated and degraded land requiring reclamation and management } \\
\text { within the overall area of the voivodship (as \%) }\end{array}$ & $\mathrm{D}$ \\
\hline 5 & $\begin{array}{c}\text { The proportion of agricultural land threatened by wind erosion within the overall area } \\
\text { of the voivodship (as \%) }\end{array}$ & $\mathrm{D}$ \\
\hline 6 & $\begin{array}{c}\text { The proportion of agricultural and forested land threatened by water erosion within } \\
\text { the overall area of the voivodship (as \%) }\end{array}$ & $\mathrm{D}$ \\
\hline 7 & $\begin{array}{l}\text { The proportion of agricultural and forested land threatened by gully erosion within } \\
\text { the overall area of the voivodship (as \%) }\end{array}$ & $\mathrm{D}$ \\
\hline 8 & $\begin{array}{l}\text { Consumption of artificial fertilizers in terms of pure ingredient over the economic } \\
\text { year } 2011 / 2012 \text { (in kg/ha of agricultural land) }\end{array}$ & $\mathrm{D}$ \\
\hline 9 & Exploitable underground water resources in Poland (in cubic hectometres per year) & $\mathrm{S}$ \\
\hline 10 & Water withdrawal for the needs of the national economy and population (in dam $3 / \mathrm{km}^{2}$ ) & $\mathrm{D}$ \\
\hline 11 & Consumption of water for production purposes in closed cycles (as $\%$ of total consumption) & $\mathrm{D}$ \\
\hline 12 & Water consumption in households (in $\mathrm{m}^{3}$ per capita in cities) & $\mathrm{D}$ \\
\hline 13 & $\begin{array}{l}\text { Amount of industrial and municipal wastewater discharged into waters or into the ground } \\
\text { (in } \mathrm{m}^{3} \text { per } \mathrm{km}^{2} \text { of voivodship area) }\end{array}$ & $\mathrm{D}$ \\
\hline 14 & The proportion of treated wastewater to all wastewater requiring treatment (\%) & S \\
\hline 15 & $\begin{array}{l}\text { Population in cities connected to wastewater treatment plants (as \% of total population of } \\
\text { cities) }\end{array}$ & $\mathrm{S}$ \\
\hline 16 & $\begin{array}{c}\text { Population in villages connected to wastewater treatment plants (as } \% \text { of total population } \\
\text { of villages) }\end{array}$ & S \\
\hline 17 & Degree of reduction in generated particulate pollutants in especially noxious plants (as \%) & S \\
\hline 18 & Degree of reduction in generated gaseous pollutants in especially noxious plants (as \%) & S \\
\hline 19 & Area of special natural value protected by law (as \% of voivodship area) (S) & S \\
\hline 20 & The area of parks, lawns and estate green belts (in $\mathrm{m}^{2}$ per capita) & S \\
\hline 21 & Industrial waste generated during a year (in $\mathrm{t} / \mathrm{km}^{2}$ ) & $\mathrm{D}$ \\
\hline 22 & Recovered waste (as \% of generated wastes) & $\mathrm{S}$ \\
\hline 23 & Waste accumulated so far on own landfill areas (in $\left.\mathrm{t} / \mathrm{km}^{2}\right)$ & $\mathrm{D}$ \\
\hline 24 & $\begin{array}{l}\text { The proportion of municipal waste collected selectively in relation to the total amount } \\
\text { of collected municipal waste (as \%) }\end{array}$ & $\mathrm{S}$ \\
\hline 25 & Levels of recycling of packaging waste (as \%) & $\mathrm{S}$ \\
\hline 26 & $\begin{array}{c}\text { The proportion of plants exceeding permissible noise levels in relation to the overall } \\
\text { number of entities of this type controlled (as \%) }\end{array}$ & $\mathrm{D}$ \\
\hline
\end{tabular}

Source: own compilation based on Central Statistical Office data (GUS 2013)

and protection of the environment). For this purpose synthetic measures are constructed. Each of the multidimensional spatial objects (e.g. region) is assigned a metric value that allows for their linear ordering (Kijek 2014). Taxonomic analysis provides an estimate of the level of diversity of objects (e.g., regions) described by a set of statistical characteristics (e.g., indicators). Linear ordering is used to establish a hierarchy of individual objects based on their distance from a reference (e.g., the region for which a particular index is a reference). In a linear hierarchy the maximum degree is 1 (Łogwiniuk 2011).

The specificity of competition processes, particularly in regional terms, has a multi-faceted nature. So the selection of features for analysis is characterized by a particular multidimensionality, and thus allows for many different approaches to the problem of variable selection (Hydzik 2012). Therefore, evaluation of the environmental competitiveness of regions was conducted based on the indicators of state, pressure, and environmental protection. These were chosen according to the data available from the Environmental Protection Statistical Yearbooks 2005 and 2013 in such a way that the final set of indicators would be able to answer the main question: which Polish regions belong to high, medium and low environmental competitiveness groups? In addition, the diagnostic variables (indicators) were selected and designed to take into account the most important characteristics of the analysed phenomenon (the environmental competitiveness of regions). A set of 26 indicators and their characters ( $\mathrm{S}$ - stimulant, $\mathrm{D}$ - de-stimulant) are presented in table 1. 
Stimulants (selected indicators) are explanatory (independent) variables whose increased values cause an increased value in the dependent variable (environmental competitiveness of regions), while de-stimulants are explanatory variables whose increased values induce a decrease in the value of the dependent variable.

Since the set of independent variables (metrics) contains variables that cannot be aggregated directly using appropriate standardization, normalization formulas were applied. Among the normalization formulas, unitarization methods were selected based on the interval of a normalized variable. This was dictated by the fact that it can be used for three types of variables: stimulants, de-stimulants, and nominants. The zero unitarization method was used as follows (Kijek 2013; Kukuła 2000):

- For stimulant:

$z_{i k}^{t}=\frac{x_{i k}^{t}-\min _{t} \min _{i}\left\{x_{i k}^{t}\right\}}{\max _{t} \max _{i}\left\{x_{i k}^{t}\right\}-\min _{t} \min _{i}\left\{x_{i k}^{t}\right\}}$

- For de-stimulant:

$z_{i k}^{t}=\frac{\max _{t} \max _{i}\left\{x_{i k}^{t}\right\}-x_{i k}^{t}}{\max _{t} \max _{i}\left\{x_{i k}^{t}\right\}-\min _{t} \min _{i}\left\{x_{i k}^{t}\right\}}$

where:

$z_{i k}^{t}$ is the normalized value of the $k$ characteristic in the $i$ object in the $t$ period $(t=1,2, \ldots, T)$

$x_{i k}^{t}$ is the initial value of the $k$ characteristic in the $i$ object in $t$ period

Diagnostic features normalized in the abovementioned way take their value from the interval $[0,1]$. The closer the value is to unity, the better the situation in terms of the feature under investigation, and the closer the value is to zero, the worse the situation.

Among the methods for creating synthetic metrics, a nonreference method with a system of constant weights was selected. This was influenced by the normalization method previously used for the investigated features. Taxonomic metrics for environmental competitiveness over the respective periods were built as follows:

$z_{i}^{t}=\frac{1}{k} \sum_{k=1}^{m} z_{i k}^{t}$

Table 2 contains a cumulative presentation of the results obtained by individual voivodships in 2004 and 2012 .

\section{Results}

The analysis conducted shows that in 2012, the province of Subcarpathia was characterized by the highest level of environmental competitiveness. The taxonomic measurement of the environmental competitiveness for this region was estimated at 0.671 . The worst score in the assessment was observed in Swietokrzyskie (0.347). For 2004 and 2012, five classes of voivodships were distinguished according to their level of environmental competitiveness (Fig. 1 \& 2).

When compared to 2004 , slight changes were reported in the ranking of the environmental competitiveness of Polish regions. In 2004, Warmia-Masuria, Kuyavia-Pomerania, and Subcarpathia were among the top three provinces. In 2012, Subcarpathia ranked first, followed by the Pomerania and Kujavia-Pomerania provinces. Minor reshuffles were also reported in terms of the provinces that were at the bottom of the ranking. In 2004, the last
Table 2. Environmental competitiveness of Polish voivodships

\begin{tabular}{|c|c|c|c|c|c|c|}
\hline \multirow[t]{2}{*}{ Voivodships } & \multicolumn{2}{|c|}{$\begin{array}{c}\text { Taxonomic } \\
\text { metrics }\end{array}$} & \multirow[t]{2}{*}{ Change } & \multicolumn{2}{|c|}{$\begin{array}{c}\text { Ranking in } \\
\text { Poland }\end{array}$} & \multirow[t]{2}{*}{ Change } \\
\hline & 2004 & 2012 & & 2004 & 2012 & \\
\hline Lower Silesia & 0.498 & 0.484 & -0.014 & 11 & 12 & -1 \\
\hline $\begin{array}{l}\text { Kuyavia- } \\
\text { Pomerania }\end{array}$ & 0.628 & 0.620 & -0.008 & 2 & 3 & -1 \\
\hline Lublin & 0.560 & 0.527 & -0.033 & 8 & 8 & 0 \\
\hline Lubusz & 0.592 & 0.611 & 0.019 & 4 & 4 & 0 \\
\hline Lodzkie & 0.520 & 0.508 & -0.012 & 9 & 10 & -1 \\
\hline Lesser Poland & 0.481 & 0.481 & 0.000 & 12 & 13 & -1 \\
\hline Masovia & 0.410 & 0.469 & 0.059 & 15 & 14 & 1 \\
\hline Opole & 0.573 & 0.561 & -0.012 & 7 & 6 & 1 \\
\hline Subcarpathia & 0.607 & 0.671 & 0.064 & 3 & 1 & 2 \\
\hline Podlaskie & 0.583 & 0.539 & -0.044 & 6 & 7 & -1 \\
\hline Pomerania & 0.592 & 0.621 & 0.029 & 4 & 2 & 2 \\
\hline Silesia & 0.475 & 0.455 & -0.020 & 13 & 15 & -2 \\
\hline Swietokrzyskie & 0.389 & 0.347 & -0.042 & 16 & 16 & 0 \\
\hline $\begin{array}{l}\text { Warmia- } \\
\text { Masuria }\end{array}$ & 0.658 & 0.602 & -0.056 & 1 & 5 & -4 \\
\hline Greater Poland & 0.516 & 0.505 & -0.011 & 10 & 11 & -1 \\
\hline $\begin{array}{c}\text { West } \\
\text { Pomerania }\end{array}$ & 0.466 & 0.521 & 0.055 & 14 & 9 & 5 \\
\hline
\end{tabular}

Source: own research based on Central Statistical Office data (GUS 2005, 2013)

three places were occupied by the Swietokrzyskie, Masovia, and West Pomerania provinces; while in 2012, Swietokrzyskie still ranked last, but with the Silesian and Masovia provinces ranked directly above.

When comparing the base period, to 2012, five provinces improved their nationwide position(West Pomerania, Pomerania, Subcarpathia, Opole and Masovia),while the position of a further three did not change (Lublin, Lubusz, Swietokrzyskie), and the other eight provinces deteriorated. The largest increase was reported in West-Pomeranian voivodship; an improvement of five places from $14^{\text {th }}$ to $9^{\text {th }}$ place in the ranking. On the other hand, the biggest drop, which was four places, was noted in the case of the Warmia-Masuria province: from $1^{\text {st }}$ to $5^{\text {th }}$.

How, therefore, should the results be interpreted in relation to a specific region? What factors contributed to the high level of environmental competitiveness of a selected region?

Some of the top regions in Poland with a high level of environmental competitiveness, are the Subcarpathia, Pomerania and Kuyavia-Pomerania voivodships. The study of the Subcarpathia province showed that in 2012 this region received above-average scores nationally for 18 of the 26 indicators considered (almost 70\%). The main environmental advantages include:

1. the highest level of air protection in the industrial sector. Among especially burdensome enterprises emitting dust and gas pollutants in the Subcarpathia province, all possess the apparatus to reduce dust pollutants (national average: $88 \%$ ) and nearly $25 \%$ possess apparatus to reduce gas pollutants (national average: $14 \%$ ). 


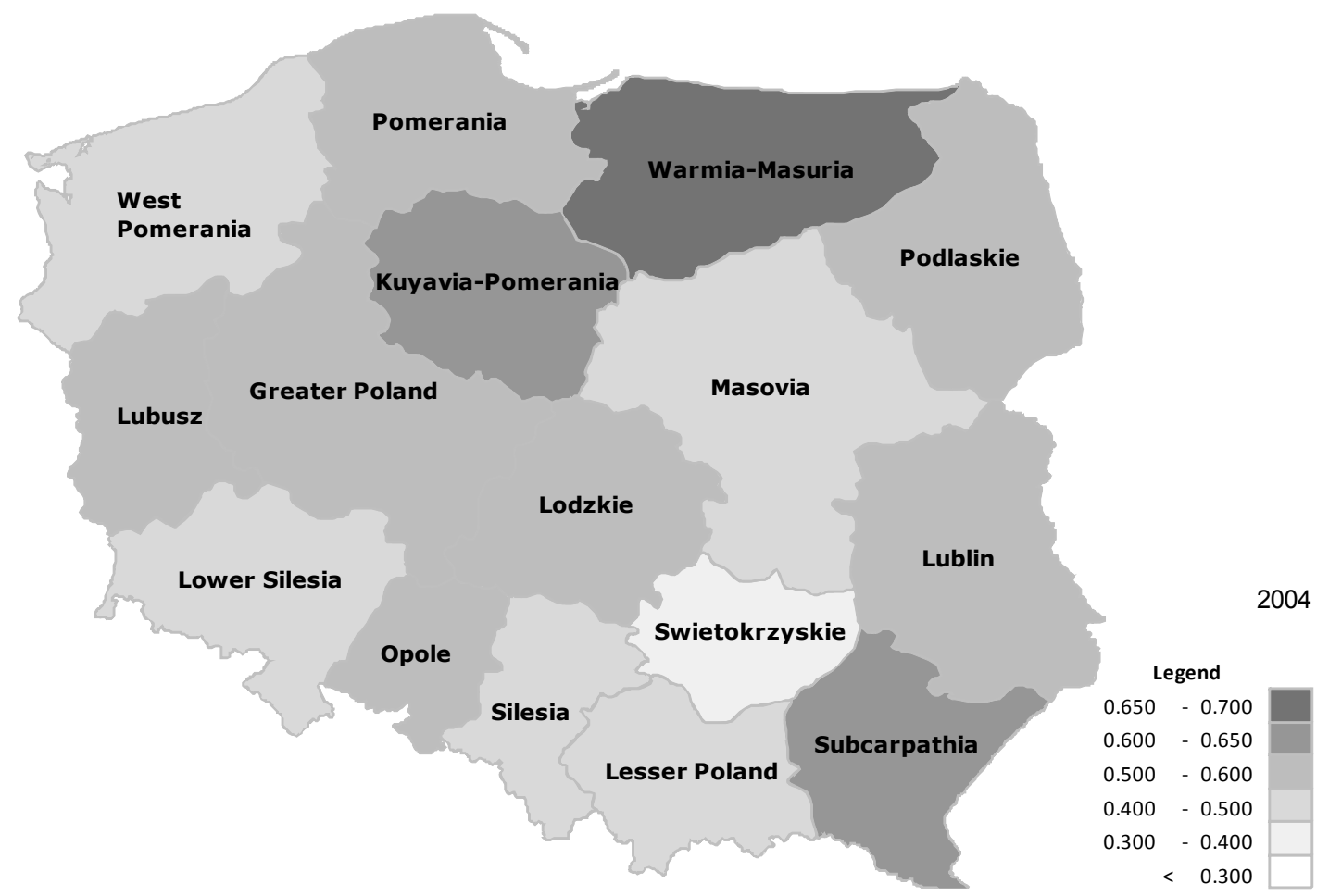

Figure 1. Environmental competitiveness of Polish regions in 2004

Source: own compilation

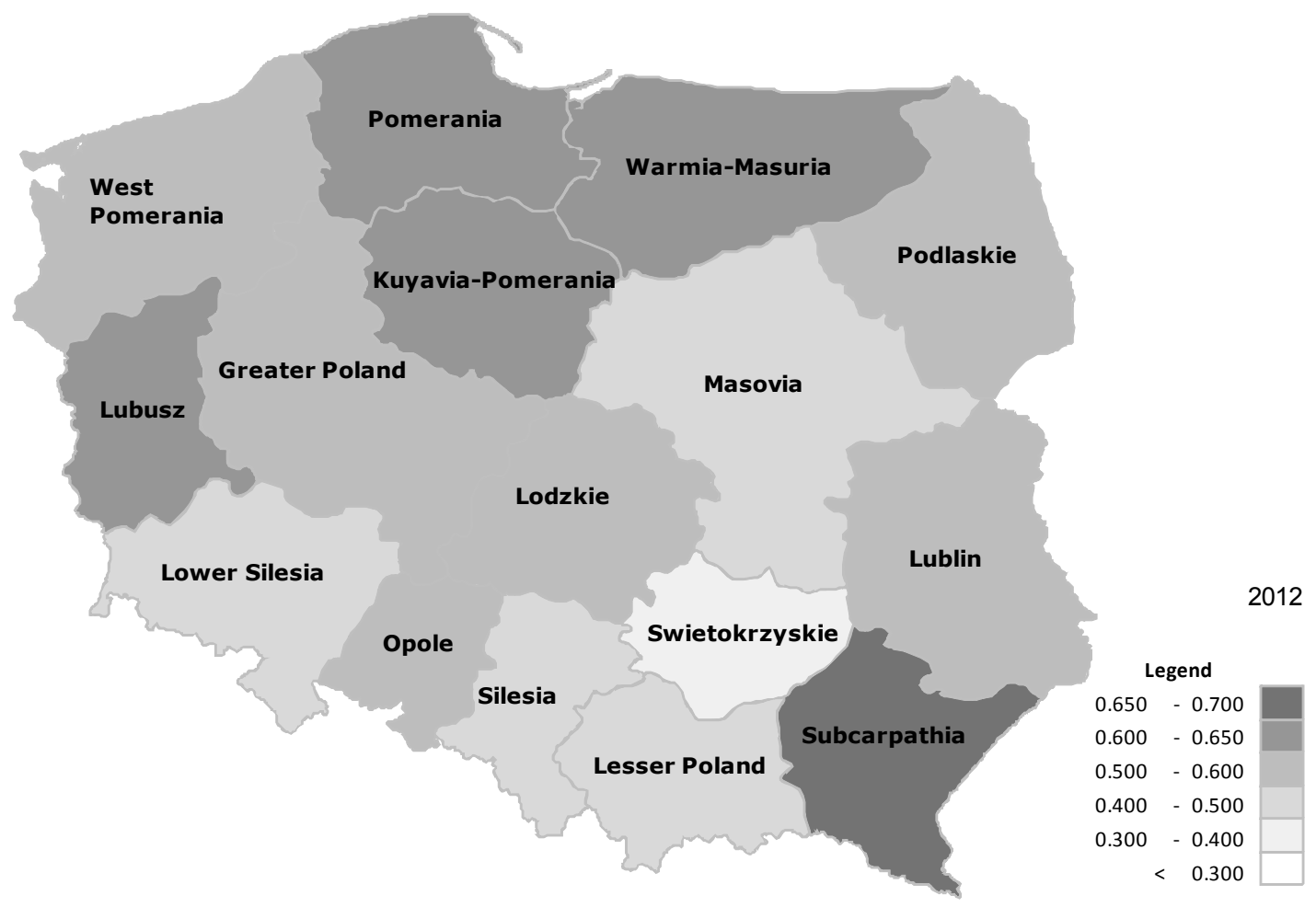

Figure 2. Environmental competitiveness of Polish regions in 2012

Source: own compilation 
2. a high contribution of areas characterized by specific natural values. Nearly $45 \%$ of the Subcarpathia province constitutes protected areas. In this respect, this region is the $4^{\text {th }}$ in Poland after Swietokrzyskie (nearly 65\%), Lesser Poland (52\%), and Warmia-Masuria (nearly 47\%). In addition, Subcarpathia ranks second in Poland in terms of contribution to total forest area (nearly $41 \%$ ).

3. a relatively high level of development in environmental protection infrastructure for rural areas. When compared to the national average (34\%), the contribution of rural population to wastewater treatment plants facilities is relatively high and is estimated at nearly $51 \%$, which has the Subcarpathia province ranked $2^{\text {nd }}$ in Poland, followed by the Pomerania province (nearly $55 \%$ ).

4. a predisposition for dynamic ecological production development. In the 2011/2012 business year, farming in the Subcarpathia province was characterized by the lowest level of fertilizer use (nearly $60 \mathrm{~kg} / \mathrm{ha}$ of agricultural land, with the national average at a level of more than $122 \mathrm{~kg} /$ ha). Taking into account the large stretches of devastated and degraded lands in Poland unaffected by fertilizer use, and the equally unaffected agricultural soils menaced by wind erosion, it can be concluded that this region exhibits significant potential for ecological development.

Individual regions differ in terms of their environmental potential. The fact that some of the provinces are characterized by a low level of environmental competitiveness does not indicate that pro-environmental developmental factors cannot be distinguished. For instance, the lowest rated province, Swietokrzyskie, is characterized by having the largest percentage area with special natural values $(64.5 \%$, national average $33.5 \%)$. This potential certainly predisposes the region for development of different forms of tourism and recreation.

\section{Conclusions}

The competitiveness of the regions cannot be considered separately from the quality of the environment in a given area, which largely determines the scope of business and social activity. Natural capital is increasingly being seen (also in the area of economics) as an important element of competitive advantage at the regional level. The natural environment is a source of valuable raw materials and energy, provides geographical space, and remains a place of residence, recreation and field of human activity.

The environmental competitiveness of a region is a concept that fits perfectly with the basic assumption of the sustainable development of regions. Proper use of environmental potential will firstly allow the generation of additional economic effects, secondly, will contribute to further improvement of the state of the environment and thus produce synergistic effects, and thirdly, will favour realization of social goals by decreasing unemployment and a generally improving quality of life.

Based on the studies conducted, it can be concluded that the highest level of environmental competitiveness in Polish regions are observed in provinces such as: Subcarpathia, Pomerania and Kuyavia-Pomerania, while provinces such as Swietokrzyskie, Silesia and Masovia were evaluated with the lowest scores.

The analyses presented in this paper are based on one of the taxonomic methods, known as the zero unitarization method. It would be appropriate to continue this studies using a more advanced statistical approach, especially taking into account the Hellwig's method and the relative weighting of each indicator in the achievement of regional advantage in terms of environmental competitiveness. There is also a question about the indicators selected for the analysis. It may be appropriate to consider extending the set of indicators, which would allow for an even more accurate assessment of the environmental competitiveness of regions.

\section{Acknowledgements}

This research was supported financially by the Ministry of Science and Higher Education in Poland. Grant no. RKO/MN/11

\section{References}

Bartmann, H 1996, Umweltökonomie - Ökologische Ökonomie, Verlag W. Kohlhammer, Stuttgart.

Borozan, D 2008, 'Regional competitiveness: some conceptual issues and policy implications' in Interdisciplinary management research IV, eds D Barkovic \& B Runzhiemer, Faculty of Economics in Osijek, Osijek, pp.50-63.

Camagni, R (2008), 'Regional competitiveness: towards a concept of territorial capital' in Modelling regional scenarios for the enlarged Europe. European Competiveness and Global Strategies, eds R Capello et al., Springer Berlin Heidelberg, Berlin, pp. 33-47.

Camagni, R \& Capello, R (2013), 'Regional competitiveness and territorial capital: a conceptual approach and empirical evidence from the European Union', Regional Studies, Volume 47, Issue 9, pp. 1383-1402.

Constantin, D-L 2006, 'Recent advances in territorial competition and competitiveness analysis', Romanian Journal of European Affairs, vol. 6, no. 3, pp.71-81.

Costanza, R \& Daly, H E 1992, 'Natural capital and sustainable development', Conservation Biology, vol. 6, no. 1, pp.37-46.

Degórski, M 2010, 'Socio-economic responses to the environment and ecosystem services in regional development', Geographia Polonica, 83, 2, pp.83-95.
Ehrlich, P R \& Wilson, E O 1991, 'Biodiversity studies: science and policy', Science, 253, pp.758-762.

Ekins, P, Simon, S, Deutsch, L, Folke C \& De Groot, R 2003, 'A framework for the practical application of the concepts of critical natural capital and strong sustainability', Ecological Economics, 44, 2-3, pp.165-185.

GUS 2005, Ochrona Środowiska 2005, GUS, Warszawa.

GUS 2013, Ochrona Środowiska 2013, GUS, Warszawa.

Hellwig, Z 1968, 'Zastosowanie metody taksonomicznej do typologicznego podziału krajów ze względu na poziom ich rozwoju oraz zasoby i strukturę wykwalifikowanych kadr', Przegląd Statystyczny, no. 4, pp.307-326.

Hydzik, P 2012, 'Zastosowanie metod taksonomicznych do oceny poziomu rozwoju społeczno-ekonomicznego powiatów województwa podkarpackiego', Zeszyty Naukowe Politechniki Rzeszowskiej, nr 286, z. 19 (2), pp. 17-32.

Jędrusik, M 2014, 'The elusive sustainable development of small tropical islands', Miscellanea Geographica - Regional Studies on Development, vol. 18, no. 3, pp. 26-30. DOI: 10.2478/mgrsd-2014-0026.

Kasztelan, A 2010, 'Środowiskowa konkurencyjność regionów próba konceptualizacji', Problemy Ekorozwoju-Problems of Sustainable Development, vol. 5, no. 2, pp.77-86. 
Kasztelan, A 2011, 'Ocena środowiskowej konkurencyjności regionów w Polsce', Prace Naukowe Uniwersytetu Ekonomicznego we Wrocławiu, no. 166, pp.258-268.

Kasztelan, A 2013a, 'A comparative analysis of the environmental competitiveness of Lubelskie and Zachodniopomorskie voivodships', Rocznik Ochrona Środowiska-Annual Set The Environment Protection, vol. 15, pp.637-648.

Kasztelan, A 2013b, 'Regional development based on environmental competitive advantages - a comparative analysis of Polish voivodships', Comparative Economic Research. Central and Eastern Europe, vol. 16, iss. 2, pp.105-122.

Kijek, A 2013, Ryzyko sektorowe przemysłu przetwórczego. Modelowanie i ocena. Wydawnictwo UMCS, Lublin.

Kukuła, K 2000, Metoda unitaryzacji zerowanej, PWN, Warsaw.

Łogwiniuk, K 2011, 'Zastosowanie metod taksonomicznych w analizie porównawczej dostępu do infrastruktury ICT przez młodzież szkolną w Polsce', Economy and Management, 1/2011, pp.7-23.

Martin, R (2005), Thinking about regional competitiveness: critical issues, East Midlands Regional Development Agency, Nottingham.

Madej, T 2002, 'Funkcje pełnione przez środowisko przyrodnicze' in Gospodarka a środowisko przyrodnicze, Wyd. Naukowe Uniwersytetu Szczecińskiego, Szczecin, pp.79-88.
Malovics, G 2007, The role of natural capital in regional development, 2nd Central European Conference in Regional Science - CERS, Technical University of Košice, Košice, pp. 648-655.

Michałowski, A 2012, 'Ecosystem services in the light of a sustainable knowledge-based economy', Problemy Ekorozwoju-Problems of Sustainable Development, vol. 7, no. 2, pp. 97-106.

Pawłowski, A 2013, 'Sustainable development and globalization', Problemy Ekorozwoju- Problems of Sustainable Development, vol. 8 no. 2, pp. 5-16.

Rucinska, S. \& Rucinsky, R 2007, Factors of regional competitiveness, 2nd Central European Conference in Regional Science - CERS, Technical University of Košice, Košice, pp. 902-911.

Sztumski, W 2009, 'Mitologia rozwoju zrównoważonego', Problemy Ekorozwoju - Problems of Sustainable Development, vol 4, no. 2, pp. 13-23.

Wokoun, R, Damborský, M, Kouriilová, J \& Krejčová, N 2012, The competitiveness of regions in the EU, ERSA conference papers, Available from: http://www-sre.wu.ac.at/ersa/ ersaconfs/ersa12/e120821aFinal00790.pdf. [09.04.2015] 